chemotherapy. Fluorouracil is the most effective agent now available for the systemic treatment of advanced and metastatic disease. Its value as adjuvant treatment at the time of initial surgery, however, is controversial. Li and Ross ${ }^{2}$ reported encouraging results with fluorouracil given four to six weeks after surgery. Rousselot et al $^{12}$ used a combination of intraluminal and intravenous fluorouracil in patients with Dukes's category C disease with some improvement. Other reports have shown little or no benefit when side effects are taken into account, although the combination of fluorouracil and BCG may be more effective. ${ }^{13}$

The liver is a favourable site for colorectal metastases. Up to half of the tumours give rise to liver metastases, and once they become established the outlook is bleak. Bengmark and Hafström $^{5}$ reported a survival time of five to seven months, Jaffe et al a mean of 146 days, ${ }^{14}$ and Pestana et al a mean of nine months. ${ }^{15}$ The survival rate appears to be the same in patients with hepatic metastases whether a palliative resection of the colon or some form of bypass procedure is carried out. ${ }^{5}$ This suggests that hepatic metastases are a chief cause of death in these patients.

Our study was designed to assess whether adjuvant liver perfusion with fluorouracil would prevent the development of secondary deposits in the liver after resection for colorectal cancer. Malignant cells are thought to enter the portal circulation either spontaneously or during surgery. Tumour cells have been recovered from the blood of major mesenteric venous channels in up to $32 \%$ of cases of colorectal cancer, ${ }^{6}$ including Dukes's category A. Though most of these cells perish, some remain to form a micrometastasis. ${ }^{7}$ Nitrogen mustard given when these cells are inoculated into rats reduces the number of "takes" of the malignant emboli, ${ }^{16}$ and on this theoretical basis fluorouracil is given as an adjuvant liver perfusion. Cell growth kinetics suggest that cell-cycle-specific chemotherapeutic agents should be more effective against small numbers of tumour cells than against bulky tumours that grow slowly. ${ }^{17}$ Thus fluorouracil given directly into the portal circulation in high concentrations is more likely to be effective in destroying "tumour emboli." Heparin is also given, chiefly to discourage portal vein thrombosis but also to prevent a fibrin clot developing around the tumour cells. ${ }^{7}$
Our initial results have been encouraging. The postoperative morbidity and mortality were no worse than in the control group. The liver can presumably take the brunt of the high dosage and limits the untoward systemic side effects that would otherwise occur with smaller doses given intravenously. The patients have been carefully followed up for a mean of 15.5 months. Six deaths in the control group due to recurrent disease have occurred and only one in the perfusion group. There was histological evidence of liver metastases in four patients and highly suggestive evidence (on liver scan) in a further two patients in the control group, but no suggestion of liver metastases in any patient in the perfusion group. The numbers are so far too small and the periods of follow-up too short, however, for accurate statistical analysis.

Possibly techniques designed to prevent the development of liver metastases could be combined with other methods designed to limit local recurrence, such as immunotherapy ${ }^{13}$ or local radiotherapy, in an attempt to improve the overall prognosis for patients with colorectal cancer.

\section{References}

1 Slaney, G, Modern Trends in Surgery, vol 3. London, Butterworths, 1971. ${ }^{2} \mathrm{Li}, \mathrm{M} \mathrm{C}$, and Ross, S T, Fournal of the American Medical Association, 1976, 235, 2825.

${ }^{3}$ Higgins, G A, et al, Archives of Surgery, 1971, 102, 339.

${ }^{4}$ Lawrence, W, Annals of Surgery, 1975, 181, 616.

5 Bengmark, S, and Hafström, L, Cancer (Philadelphia), 1969, 23, 198.

${ }^{6}$ Fisher, E R, and Turnbull, R B, Surgery, Gynecology and Obstetrics, $1955,100,102$.

: Hilgard, D, et al, European fournal of Cancer, 1972, 8, 347.

${ }^{8}$ Kessler, R E, and Zimmon, D S, Surgery, Gynecology and Obstetrics, 1967, 124, 594.

${ }^{9}$ Lavoire, P, Legare, A, and Vialetta, A, American fournal of Surgery, 1967, 114,822 .

${ }^{10}$ Man, B, Kraus, L, and Pikielny, S, Vascular Surgery, 1974, 8, 193.

11 Dukes, C E, fournal of Pathology and Bacteriology, 1940, 50, 527.

12 Rousselot, L M, et al, Diseases of the Colon and Rectum, 1972, 15, 169.

13 Mavligit, G M, et al, Lancet, 1976, 1, 871.

$14 \mathrm{Jaffe}, \mathrm{B}$ M, et al, Surgery, Gynecology and Obstetrics, 1968, 127, 1.

${ }_{15}$ Pestana, C, et al, American fournal of Surgery, 1964, 108, 826.

16 Morale, G F, et al, Annals of Surgery, 1957, 146, 588.

17 Schabel, F M, Cancer (Philadelphia), 1975, 35, 15.

\title{
Plasma fenfluramine levels, weight loss, and side effects
}

\author{
J A INNES, M L WATSON, M J FORD, J F MUNRO, MARGARET E STODDART, D B CAMPBELL
}

British Medical fournal, 1977, 2, 1322-1325

\section{Summary}

Fifty women with refractory obesity received fenfluramine for 20 weeks. Every two weeks details of weight change, drug dose, degree of anorexia, and any side effects were recorded and plasma was obtained for fenfluramine and norfenfluramine measurements. Of the 41 patients available for final analysis 26 achieved a maxi-

Eastern General Hospital, Edinburgh

J A INNES, MRCP, registrar

$M$ L WATSON, MRCP, senior house officer

$M$ J FORD, MRCP, medical registrar

J F MUNRO, FRCPED, consultant physician

MARGARET E STODDART, SRD, dietitian

Servier Research Institute, Greenford, Middlesex

D B CAMPBELL, BSC, MRIC, research director mum plateau dose of $160 \mathrm{mg} /$ day. Plasma fenfluramine concentrations did not correlate with the degree of anorexia or with the incidence of side effects other than the severity of dream disturbance. There was a highly significant relation between weight loss and plasma fenfluramine and norfenfluramine concentrations and also between weight loss and the presence of sustained anorexia. Women who achieved mean plateau concentrations over $200 \mathrm{ng} / \mathrm{ml}$ lost a mean of $8.8 \mathrm{~kg}$ while those with concentrations less than $100 \mathrm{ng} / \mathrm{ml}$ lost a mean of only $2 \cdot 1 \mathrm{~kg}$.

When fenfluramine is prescribed in refractory obesity the dose should be increased stepwise until either satisfactory weight loss is achieved or troublesome side effects appear.

\section{Introduction}

Fenfluramine is an effective anti-obesity agent, but its modes of action are controversial, and clinical response to treatment varies. 
Previous studies have failed to explain why some patients do well and others do not, though it has been suggested that effective weight loss will occur when satisfactory plasma concentrations of fenfluramine and its metabolites are achieved. ${ }^{1}$ It has also been suggested that the weight-losing effect of fenfluramine may be related to the patient's vitamin C status." We attempted to correlate fenfluramine dosage, weight loss, and side effects with plasma fenfluramine and norfenfluramine concentrations in patients with refractory obesity.

\section{Patients and methods}

Fifty women, all of whom had refractory obesity, ${ }^{3}$ were studied over 20 weeks. Those known to be intolerant to fenfluramine were excluded. All received fenfluramine (20-mg tablets) and the dose was increased and decreased in a stepwise manner over the initial and final four weeks to a maximum daily intake of $160 \mathrm{mg}$ or until troublesome side effects appeared, limiting further increments.

At the beginning of the study the women were told to take carbohydrate-restricted diet, designed to give $4.18 \mathrm{MJ}$ (1000 kcal) and not more than $40 \mathrm{mg}$ vitamin $\mathrm{C}$ daily. As an additional facet of the study half the women received vitamin $\mathrm{C}$ supplements $(600 \mathrm{mg} /$ day $)$ and half received matched placebo tablets in a double blind manner. The initial weight of all subjects was recorded and the percentage in excess of standard weight was calculated.

Subjects attended every two weeks, when details of diet and tablet compliance, weight change, degree of appetite suppression, and side

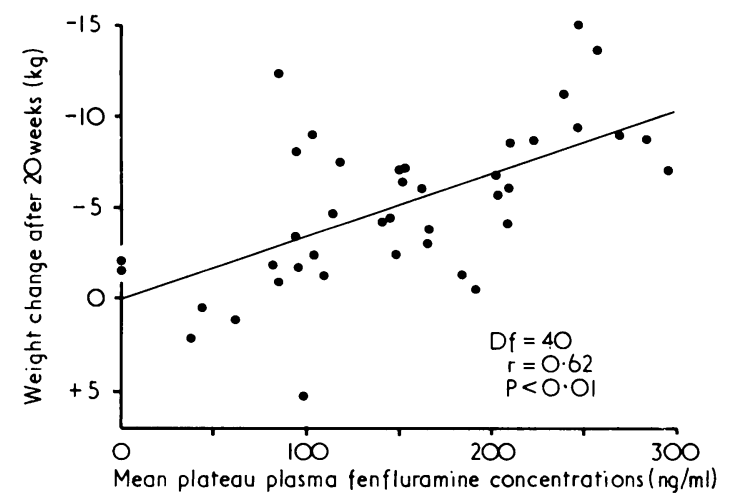

FIG 1-Relation between mean plateau plasma fenfluramine concentrations and weight change after 20 weeks' treatment. effects, if present, were noted. The side effects recorded included changes in bowel habit, energy, mood, and dreaming pattern and dry mouth. The degree of appetite suppression and the severity of the side effects was scored as shown in table II.

At each attendance from the fourth to the 16th week venous blood was taken into heparinised tubes and centrifuged, and the plasma was deep-frozen within the hour until analysis. Plasma concentrations of fenfluramine and norfenfluramine were determined by gas-liquid chromatography using the modification of the procedure of Campbell. The mean plasma fenfluramine and norfenfluramine concentrations were calculated for the plateau period-that is, the fourth to 16th week. The significance of the data was obtained by least squares linear regression analysis to determine correlations and by unpaired Student's $t$ test to determine group differences. An $\mathrm{F}$ test was undertaken on al paired data. The statistics were computed on a Wang 600-14 programmable calculator with a 602 printing typewriter and $P$ values obtained from Documenta Geigy."

\section{Results}

Five patients defaulted from the study and three were withdrawn, one because of pregnancy, one for personal reasons, and one because of intolerable side effects, which included nausea, vomiting, and profound lethargy. A further patient was not included in the analysis because the blood samples were lost. Of the 41 subjects analysed 22 had received supplementary vitamin $\mathrm{C}$ and 19 the matched placebo. There was no significant difference between the two groups in age, initial weight, degree of obesity, and weight loss. Further analysis was therefore undertaken without regard to vitamin $\mathrm{C}$ intake.

Table I shows the mean initial weight, fenfluramine concentrations, and changes in values after treatment.

Fifteen patients could not achieve the maximum daily intake of 160 $\mathrm{mg}$ fenfluramine because of troublesome side effects and the dose was accordingly adjusted. In most patients the limiting factor was either diarrhoea or tiredness. The overall incidence of side effects is shown in table II. The mean plateau dose of fenfluramine was $134 \mathrm{mg} /$ day (60-160). Fenfluramine and norfenfluramine were never detected in the plasma of two patients and presumably neither took the drug, though both said they were doing so. The mean plateau plasma concentrations of fenfluramine and norfenfluramine in the remaining 39 patients were $158 \mathrm{ng} / \mathrm{ml}$ and $72 \mathrm{ng} / \mathrm{ml}$ respectively.

There was a significant correlation between weight loss and plasma fenfluramine and norfenfluramine concentrations $(r=0.6018 ; P<0.001$ and $\mathrm{r}=0.4457 ; \mathrm{P}<0.001$ respectively) (figs 1 and 2 ). Three patients gained weight, two failed to lose weight, and the remainder lost weight. Mean plateau fenfluramine concentrations were less than $100 \mathrm{ng} / \mathrm{ml}$ in 13 women (including the two with no detectable drug or metabolite); 100 to $199 \mathrm{ng} / \mathrm{ml}$ in 15 ; and 200 to $299 \mathrm{ng} / \mathrm{ml}$ in 13 (table II). The mean weight losses achieved by these three groups were

TABLE I-Mean plasma fenfluramine levels $( \pm S D)$ and weight loss

\begin{tabular}{|c|c|c|c|c|c|c|c|c|}
\hline $\begin{array}{l}\text { Plasma } \\
\text { fenfluramine } \\
\text { range } \\
(\mathrm{ng} / \mathrm{ml})\end{array}$ & $\begin{array}{l}\text { No of } \\
\text { subjects }\end{array}$ & $\underset{(\text { years) }}{\text { Mean age }}$ & $\begin{array}{l}\text { Mean initial } \\
\text { weight } \\
(\mathrm{kg})\end{array}$ & $\begin{array}{c}\text { Mean "o excess } \\
\text { weight }\end{array}$ & $\begin{array}{c}\text { Mean } \\
\text { fenfluramine } \\
\text { intake } \\
(\mathrm{mg} \text { day })\end{array}$ & $\begin{array}{c}\text { Mean of mean } \\
\text { plasma } \\
\text { fenfluramine } \\
(\mathrm{ng} / \mathrm{ml})\end{array}$ & $\begin{array}{c}\text { Mean of mean } \\
\text { plasma } \\
\text { norfenfluramine } \\
\text { concentrations } \\
(\mathrm{ng} / \mathrm{ml})\end{array}$ & $\begin{array}{c}\text { Mean weight } \\
\text { loss } \\
(\mathrm{kg})\end{array}$ \\
\hline $\begin{array}{c}0-99 \\
100-199 \\
200-299\end{array}$ & $\begin{array}{l}13 \\
15 \\
13\end{array}$ & $\begin{array}{l}45 \div 14 \\
43: 11 \\
48: 12\end{array}$ & $\begin{array}{r:r}104 & 14 \\
96 & 12 \\
94 & 10\end{array}$ & $\begin{array}{l}66: 35 \\
54: 21 \\
51: 15\end{array}$ & $\begin{array}{l}135: 33 \\
141: 29 \\
149: 24\end{array}$ & $\begin{array}{r}78+22^{*+} \\
148=25^{*+} \\
239=32++\end{array}$ & $\begin{array}{l}44: 17^{*+}+ \\
75: 13^{*} \\
93: 29^{+}\end{array}$ & $\begin{array}{l}2 \cdot 1+4 \cdot 4^{+} \\
5 \cdot 1=2 \cdot 6_{+}^{+} \\
8 \cdot 8=3 \cdot 3_{+}^{+}\end{array}$ \\
\hline $\begin{array}{c}0-299 \\
\text { (and range) }\end{array}$ & 41 & $\begin{array}{l}46=12 \\
(20-70)\end{array}$ & $\begin{array}{c}99: 13 \\
(78-124)\end{array}$ & $\begin{array}{c}57-23 \\
(23-107)\end{array}$ & $\begin{array}{l}142: 29 \\
(60-160)\end{array}$ & $\begin{array}{l}158-70 \\
(35-299)\end{array}$ & $\begin{array}{c}72-29 \\
(22-144)\end{array}$ & $\begin{array}{c}5 \cdot 1+3 \cdot 5 \\
(+5 \cdot 4 \text { to }-15 \cdot 2)\end{array}$ \\
\hline
\end{tabular}

Using unpaired $t$ test $-\mathbf{P}=0.001:{ }^{*}$ for groups $1 v 2 ;$ tfor groups $2 v 3 ;+$ tgroups $1 v 3$.

TABLE II-Appetite suppression and side effects in 41 women taking fenfluramine

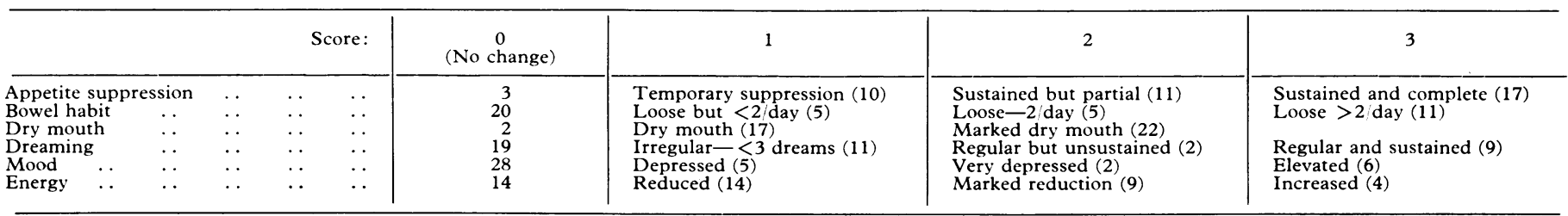




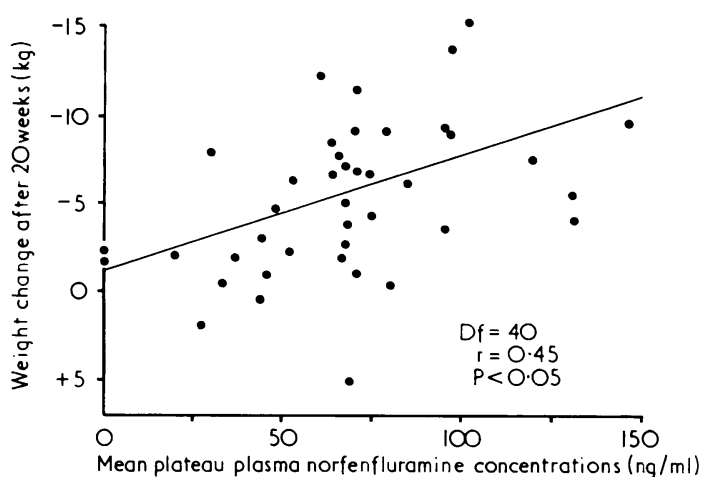

FIG 2-Relation between mean plateau plasma norfenfluramine concentrations and weight change after 20 weeks' treatment.

$2 \cdot 1 \mathrm{~kg}, 5 \cdot 1 \mathrm{~kg}$, and $8 \cdot 8 \mathrm{~kg}$ respectively (fig 3 ). In the 13 subjects who achieved mean plasma fenfluramine concentrations of $200 \mathrm{ng} / \mathrm{ml}$ or more the mean rate of weight loss was well maintained throughout the study, ranging from $0 \cdot 19-0.76 \mathrm{~kg} /$ week. Although the degree of obesity was greatest in the group with the lowest mean drug concentrations and lowest in the group with the highest concentrations, there was no statistically significant inverse relation between the initial degree of obesity and either the plasma fenfluramine or norfenfluramine concentrations $(r=-0.04518$ and $P=0.2108$ respectively).

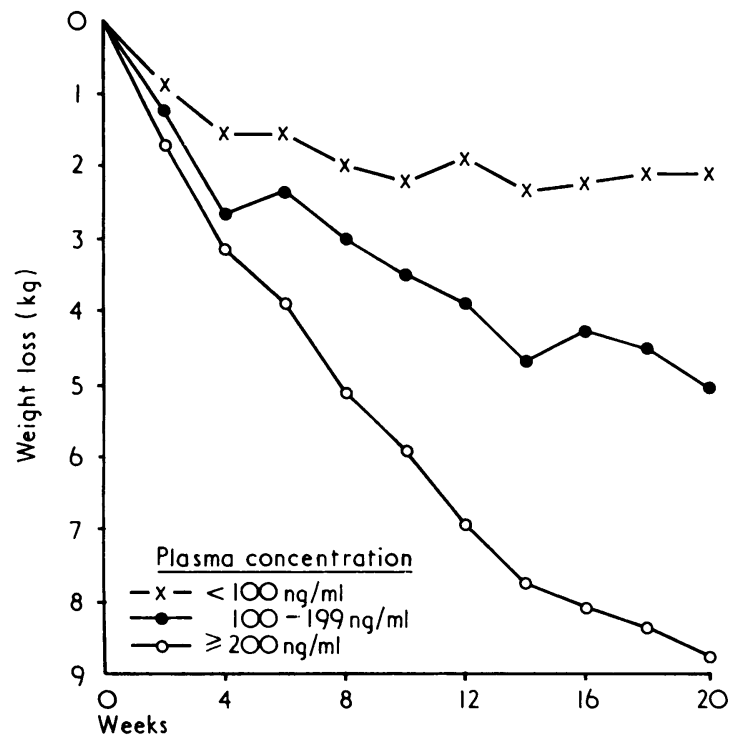

FIG 3-Plasma fenfluramine concentration and weight loss.

The mean weight loss of the 17 subjects whose appetite had been completely suppressed throughout the study was $6.8 \mathrm{~kg}$, differing significantly from the mean weight loss of $3.2 \mathrm{~kg}$ in subjects reporting no change or only temporary suppression of appetite (unpaired $t$ test : $t=2.34 ; \mathrm{P}<0.05)$.

There was a significant correlation between plasma fenfluramine concentrations and the incidence of dreaming $(\mathrm{r}=0.3507 ; \mathrm{P}<0.05)$, but the correlation was not significant for norfenfluramine $(r=0 \cdot 2902)$. Seven of the nine subjects whose dream disturbance was regular and sustained achieved plasma fenfluramine concentrations over 200 $\mathrm{ng} / \mathrm{ml}$, the other two having concentrations of less than $100 \mathrm{ng} / \mathrm{ml}$. Although the dreams were sometimes vivid, in only one patient were they of such severity as to necessitate a reduction in the dose of fenfluramine. Most of the subjects reporting irregular dream disturbance did so while the dose was being increased and thereafter stopped dreaming. One patient, however, reported excessive dreaming immediately after withdrawal of fenfluramine. There was no significant correlation between either plasma fenfluramine or norfenfluramine concentrations and the incidence or severity of any of the other side effects shown in table II.

\section{Discussion}

Although fenfluramine is chemically related to amphetamine it differs in that it increases brain serotonin concentrations by stimulating release of serotonin and blocking its neuronal uptake. ${ }^{*}$ The effect of fenfluramine on food intake can be abolished by serotonin antagonists and drugs that lower serotonin 5HT brain concentrations. ${ }^{9}$ It has been suggested that fenfluramine also has important peripheral effects on glucose and lipid metabolism, but the evidence is conflicting. ${ }^{10-14}$

Most studies that have compared fenfluramine with other weight-reducing agents for up to 36 weeks have found that it is of comparable efficacy. ${ }^{1,-21}$ The mean weight losses achieved vary greatly from one study to the next and may reflect differences in patient selection and the additional use of dietary advice and behavioural treatment. The mean rate of weight loss achieved in the present study is, however, very similar to that previously observed in similar patients.":

It has been suggested that high doses are no more effective than those usually used, ${ }^{23} 24$ and we have failed to show a relation between mean stated daily dose and either weight loss or plasma drug concentrations. The highly significant correlation between weight loss and plasma drug concentration found in this study has, however, shown that the unpredictability in individual responses to fenfluramine can be related to the variability in plasma drug concentrations. When plasma fenfluramine concentrations of $200 \mathrm{ng} / \mathrm{ml}$ or more can be achieved effective and sustained weight loss will occur for at least 20 weeks without tolerance developing. The failure to achieve such plasma drug concentrations suggests either poor patient compliance of considerable differences in drug absorption or metabolism, ${ }^{25}$ when even higher doses may be required to achieve a therapeutic effect. Sometimes the curtailing factor is the development of troublesome side effects. Their incidence can be reduced by gradual introduction and withdrawal of the drug. Apart from dreaming, there was no statistical relation between plasma drug concentrations and side effects. This does not imply that side effects are not dose related but that the level at which side effects may develop varies considerably between individual patients.

The anorectic effect of a single dose of fenfluramine has been related to plasma fenfluramine concentration. ${ }^{26}$ In this study the degree of appetite suppression was related to weight loss but there was no relation between drug concentration and subjective appetite suppression. This suggests either that fenfluramine does not produce weight loss by suppression of appetite alone or that our assessment of appetite suppression did not reliably detect changes in food intake. Recent animal studies have shown that fenfluramine stimulates satiety whereas other anti-obesity drugs produce anorexia." Similar changes have yet to be shown in obese people. If they exist it is possible that our method of assessing appetite suppression failed to recognise this distinction.

This study has confirmed our previous experience in that about half the subjects reported increased dreaming. ${ }^{2 \times}$ In most this was transient and followed increases in dose. Although most of those who dreamt excessively and regularly had high plasma drug concentrations our observations do not confirm those of a recent study that reported a uniform increase in dreaming in patients receiving relatively small doses of fenfluramine. ${ }^{29}$ In our experience excessive dreaming was related to dose only in susceptible people and was not a major therapeutic problem. The indications for the use of anti-obesity drugs, including fenfluramine, remain ill-defined. But we would recommend that the prescription of fenfluramine should always be accompanied by appropriate dietary advice and psychological support. The dose should be increased stepwise until either satisfactory weight loss is achieved or troublesome side effects develop, and when it proves effective fenfluramine should be continued, if necessary, for longer than is at present customary.

We thank Mr D Taylor for the statistical analysis; Mrs M McGowan for technical help; the outpatient nursing staff and $\mathrm{Mr}$ A Galloway, 
principal pharmacist, for their help in the study; and Mrs M Murray for secretarial help.

\section{References}

${ }^{1}$ Hossain, M, and Campbell, D B, Postgraduate Medical fournal, 1975 , 51, suppl No 1, p 155.

2 Wilson, C W M, et al, Recent Advances in Obesity Research I, ed A Howard, p 77. London, Newman, 1975.

${ }^{3}$ Seaton, D A, Rose, K, and Duncan, L J P, Scottish Medical fournal, 1964, 9, 482 .

1 Association of Life Insurance Medical Directors and Actuarial Society of America, Medico-actuarial Mortality Investigations. New York, ALIMD and ASA, 1912

5 Campbell, D B, fournal of Chromatography, 1970, 49, 442.

'Diem, K, and Linkner (eds), Documenta Geigy. Basle, CIBA Geigy, 1972

- Garattini, S, et al, Postgraduate Medical fournal, 1975, 51, suppl No 1, p 23.

* Fuxe, K, et al, Postgraduate Medical fournal, 1975, 51, suppl No 1, p 31.

9 Blundell, J E, Latham, C J, and Leshem, M B, fournal of Pharmacy and Pharmacology, 1973, 25, 492.

10 Harrison, L C, et al, Postgraduate Medical fournal, 1975, 51, suppl No 1, p 106.

1 Sulaiman, W R, Johnson, R H, and Rennie, M J, Postgraduate Medical fournal, 1975, 51, suppl No 1, p 121

12 Garrow, J S, Belton, E A, and Daniels, A, Lancet, 1972, 2, 559.

13 Petrie, J C, et al, Postgraduate Medical fournal, 1975, 51, suppl No 1, p 139

14 Ballasse, E O, La Vie Medicale au Canada Francais, 1972, special issue, p 44
${ }^{15}$ Follows, O J, British fournal of Clinical Practice, 1971, 25, 236.

${ }^{16}$ Rooyen, R J van, and Merwe, M van der, Medical Proceedings, 1971, 17,

17 Silverstone, J T, Coope, R M, and Begg, R R, British fournal of Clinical Practice, 1970, 24, 423 .

18 Gildrick, R B, Havenstein, N, and Whyte, H M, Australian and New Zealand fournal of Medicine, 1973, 3, 131

19 Steel, J M, Munro, J F, and Duncan, L J P, Practitioner, 1973, 211, 232.

20 Stunkard, A, Rickels, K, and Hesbacher, P, Lancet, 1973, 1, 503.

${ }^{21}$ Lawson, A A H, et al, Lancet, 1970, 2, 427.

${ }^{22}$ Munro, J F, Seaton, D A, and Duncan, L J P, British Medical Fournal, $1966,2,624$.

23 Datey, K K, Kelkar, P N, and Pandya, R S, British fournal of Clinical Practice, 1973, 17, 373

24 Woodward, E, Amphetamines and Related Compounds, ed E Costa and S Garattini, p 685. New York, Raven Press, 1970.

${ }^{25}$ Campbell, D B, La Vie Medicale au Canada Francais, 1973, 2, 43.

${ }^{26}$ Silverstone, J T, Fincham, J, and Campbell, D B, Postgraduate Medical fournal, 1975, 51, suppl No 1, p 167.

${ }^{27}$ Blundell, J E, International fournal of Obesity, 1977, 1, 15.

28 Innes, J A, Campbell, I W, Millar, J, and Munro, J F, Postgraduate Medical fournal, 1975, suppl No 1, p 156.

Mullen, A, Wilson, C W M, and Wilson, B P M, British Medical Fournal, 1977, 1, 70.

${ }^{29}$ Mullen, A, Wilson, C W M, and Wilson, B P M, British Medical fournal, $1977,1,70$

(Accepted 14 September 1977)

\section{SHORT REPORTS}

\section{Meningeal leukaemia in lymphoid blast crisis of chronic myeloid leukaemia}

Recent reports have drawn attention to a subgroup of patients with blast crisis of chronic myeloid leukaemia (CML) in which the blast cells have the features of lymphoblasts. " Such cases often have atypical clinical features: they may first present in blast crisis, they often respond to the type of treatment used for acute lymphoblastic leukaemia (ALL), and it is becoming apparent that they have a much higher incidence of meningeal leukaemia. We report two patients who presented with acute leukaemia in whom CML presenting in lymphoid blast crisis was diagnosed on the characteristics of the blast cells (see table), and who subsequently developed meningeal leukaemia while in haematological remission.

\section{Case reports}

Case 1-Initial complete remission was achieved in a woman of 33 with chemotherapy (including vincristine and prednisolone) and maintenance treatment given. Nine months later she presented with headaches, neck stiffness, and mild papilloedema without other neurological signs, Marrow examination showed continuing remission. The cerebrospinal fluid (CSF) contained many blast cells (white cell count $3 \cdot 33 \cdot 10^{9} / 1$ ). Treatment with dexamethasone and intrathecal methotrexate $(12.5 \mathrm{mg}$ twice weekly for four weeks) gave rapid symptomatic relief, and the CSF became clear of blast cells. Further intrathecal treatment was given at increasing intervals for two months. The symptoms did not recur, and monthly CSF examinations showed only a few blasts on one occasion. She died 18 months after diagnosis following bone marrow relapse.

Case 2-Initial complete remission was induced in a woman of 52 with vincristine and prednisolone and maintenance treatment given. Six month later she presented with headaches, left brachiofacial paraesthesiae, and mild papilloedema. Marrow examination showed continuing complete remission. CSF examination showed many blast cells (white cell count $0.69 \times 10^{9} / 1$ ) and she was treated with eight injections of intrathecal methotrexate $(12.5 \mathrm{mg}$ twice weekly). Her neurological symptoms cleared rapidly and the CSF was clear after four weeks. The CSF has remained clear, and she continues in haematological remission of blast crisis 10 months after diagnosis.

\section{Comment}

Lymphoid blast crisis was diagnosed on the basis of the $\mathrm{Ph}^{1}$ chromosome, and in case 2 myeloblastic proliferation was also present. Such lymphoid blast crisis may also occur after a typical chronic phase of CML, and may precede, follow, or coexist with myeloid blast crisis, ${ }^{1-3}$ and we feel should not be classified as ALL incidentally associated with the $\mathrm{Ph}^{1}$ chromosome.

Meningeal leukaemia in CML blast crisis is rare. It occurred only in seven of 101 patients ${ }^{4}$ but in nearly half of those achieving remission, and the meninges were often the site of first relapse. Some of these patients responded well to vincristine and prednisolone and may have had lymphoid blast crisis. In another study, ${ }^{3}$ four patients developed meningeal leukaemia, including two of the six lymphoid cases. Another patient with lymphoid disease had prophylactic craniospinal irradiation and survived two years without meningeal involvement. Atkinson et $a l^{5}$ reported two patients who developed meningeal leukaemia, both having the lymphoid type of blast crisis. At St Bartholomew's Hospital we find that meningeal leukaemia complicating typical myeloid blast crisis is extremely rare.

The high incidence of meningeal leukaemia in patients with lymphoid blast crisis is attributable to their better response to treatment and longer survival. Meningeal leukaemia occurring during haematological remission was a major clinical problem in our patients. Both responded well to intrathecal treatment, but these and other

Blast cell characteristics

\begin{tabular}{|c|c|c|c|c|c|c|}
\hline $\begin{array}{l}\text { Case } \\
\text { No }\end{array}$ & & Morphology & $\begin{array}{l}\text { Periodic acid Schiff } \\
\text { stain }\end{array}$ & Cytogenetics & ALL antiserum ${ }^{1}$ & TdT assay \\
\hline $\begin{array}{l}1 \\
2\end{array}$ & $\begin{array}{l}\text { Marrow } \\
\text { CSF } \\
\text { Marrow } \\
\text { CSF }\end{array}$ & $\begin{array}{c}\text { Lymphoid } \\
\text { Lymphoid } \\
\text { Lymphoid and myeloid* } \\
\text { Lymphoid }\end{array}$ & $\begin{array}{l}\text { Negative } \\
\text { Negative } \\
\text { Positive } \\
\text { Positive }\end{array}$ & $\begin{array}{l}\mathrm{Ph}^{1}+ \\
\mathrm{Ph}^{1}+ \\
2\left(\mathrm{Ph}^{1}+\right)\end{array}$ & $\begin{array}{l}\text { Negative } \\
\text { Positive } \\
\text { Positive } \\
\text { Positive }\end{array}$ & $\begin{array}{l}\text { High } \\
\text { High }\end{array}$ \\
\hline
\end{tabular}

* Mixed myeloblastic and lymphoblastic proliferation; other characteristics defined refer to the lymphoid population. 